\title{
UPAYA PENINGKATAN PENGETAHUAN WANITA MENGENAI KONDISI TUBUH YANG BERHUBUNGAN DENGAN PENYAKIT RONGGA MULUT MELALUI PENYULUHAN
}

\author{
Sri Tjahajawati ${ }^{1}$, Anggun Rafisa ${ }^{2}$, Rasmi Rikmasari ${ }^{3}$, dan Cucu Zubaedah ${ }^{4}$ \\ 1,2 Departemen Oral Biologi, Fakultas Kedokteran Gigi, Universitas Padjadjaran \\ ${ }^{3}$ Departemen Prostodonsia, Fakultas Kedokteran Gigi, Universitas Padjadjaran \\ ${ }^{4}$ Departemen Ilmu Kesehatan Gigi Masyarakat, Fakultas Kedokteran Gigi, Universitas Padjadjaran \\ E-mail: sri.tjahajawati@fkg.unpad.ac.id
}

\begin{abstract}
ABSTRAK. Saliva adalah cairan tubuh yang berperan penting dalam menjaga keseimbangan dan kesehatan rongga mulut Keseimbangan tersebut dapat terganggu dan menyebabkan penyakit rongga mulut apabila terdapat perubahan pada tubuh seperti kehamilan, kebiasaan merokok, menopause, diabetes mellitus dan hipertensi Pengetahuan masyarakat terutama wanita mengenai berbagai kondisi yang berhubungan dengan penyakit dalam rongga mulut harus menjadi perhatian karena perubahan hormonal pada saat kehamilan dan menopause hanya dialami oleh wanita dan anatomi serta fisiologi tubuh wanita juga berbeda dengan pria sehingga lebih berisiko terkena penyakit mulut. Salah satu upaya yang dapat dilakukan untuk meningkatkan pengetahuan tersebut adalah dengan melakukan penyuluhan sebagai bentuk dari promosi kesehatan. Peserta yang memenuhi kriteria sampel diambil secara keseluruhan (total sampling), berjumlah 81 orang wanita dari Desa Cikeruh. Penyuluhan dilaksanakan secara daring menggunakan media presentasi power point dan video edukasi melalui zoom meeting. Materi penyuluhan memaparkan diabetes melitus, hipertensi, kehamilan, menopause dan kebiasaan merokok yang bermanifestasi pada tubuh dan rongga mulut. Kegiatan penyuluhan terdiri dari tiga tahap yaitu pemberian pre-test, penyampaian materi penyuluhan dan post-test. Peningkatan nilai rata-rata peserta kegiatan penyuluhan pada posttest terlihat pada kelima topik. Sejumlah 76 orang $(93.8 \%)$ responden mengalami peningkatan nilai rata-rata pada post-test, sejumlah 5 orang $(6,2 \%)$ responden tampak memiliki penurunan nilai rata-rata post-test termasuk ke dalam kelompok ibu hamil. Kegiatan penyuluhan pada wanita di Desa Cikeruh menunjukkan peningkatan pengetahuan mengenai kondisi tubuh yang berhubungan dengan penyakit dalam rongga mulut. Kegiatan penyuluhan ini diharapkan dapat mendorong para peserta kegiatan dan masyarakat untuk merubah perilaku ke arah pola hidup yang lebih sehat.
\end{abstract}

Kata kunci: Penyuluhan; Penyakit mulut; Penyakit sistemik; Perubahan hormonal; Perokok

ABSTRACT. Saliva is a body fluid that plays an important role in maintaining balance and health of the oral cavity. This balance can be disrupted thus causing oral disease if there are changes in the body such as pregnancy, smoking habits, menopause, diabetes mellitus and hypertension. Public knowledge, especially women, about various conditions related to oral diseases should be a concern. Women have a higher risk of developing oral diseases due to hormonal changes, anatomy and physiology of their body. Providing counseling as a form of health promotion is one of the options to to increase their knowledge. The counseling participants consisted of 81 women from Cikeruh Village. The counseling was delivered online using power point media through zoom meetings. The counseling materials were descriptions of diabetes mellitus, hypertension, pregnancy, menopause and smoking habits as well as the manifestations of these conditions in the oral cavity. The activity consisted of three stages: pre-test, delivery of counseling and post-test. The increase in the post-test average score was seen in the five topics. A total of 76 people $(93.8 \%)$ respondents experienced an increase in the average score on the post-test, 5 people $(6,2 \%)$ of respondents who had a decrease in the average post-test score were pregnant women. Counseling activities for women in Cikeruh Village showed increased knowledge about body conditions related to diseases in the oral cavity. This counseling activity is expected to encourage activity participants and the community to change their behavior towards a healthier lifestyle.

\section{Keywords: Counseling; Oral disease; Systemic disease; Hormonal changes, Smoking}

\section{PENDAHULUAN}

Rongga mulut merupakan cermin kesehatan umum seseorang. Saliva adalah cairan tubuh yang terdapat pada rongga mulut dan terdiri dari campuran kompleks dari berbagai molekul. Saliva berperan penting dalam menjaga keseimbangan dan kesehatan rongga mulut seperti homeostasis, pembentukan pellikel, adhesi bakteri, pembentukan kristal hidroksi apatit, pembentukan plak, dan berfungsi sebagai pelumas dalammenjagaintegritas permukaanmukosa mulut dan bagian atas gastrointestinal. Saliva juga mengandung protein, karbohidrat, lipid, dan ion yang saling berinteraksi untuk pertahanan fisiko-kimia, antimikroba, dan penyembuhan luka. Keseimbangan tersebut dapat terganggu dan menyebabkan penyakit rongga mulut apabila terdapat perubahan atau kelainan lokal maupun sistemik pada tubuh. Kondisi tubuh yang dapat menginduksi perubahan komposisi saliva diantaranya kehamilan, kebiasaan merokok, menopause, diabetes mellitus dan hipertensi (Fábián, Fejérdy, \& Csermely, 2008).

Kehamilan memengaruhi metabolisme jaringan periodontal serta laju, kapasitas buffer, dan komposisi saliva sehingga dapat menyebabkan terganggunya integritas jaringan lunak dan keras di rongga mulut (Rockenbach, Marinho, Veeck, Lindemann, \& Shinkai, 2006). Kebiasaan merokok 
menyebabkan kalsifikasi plak gigi yang membentuk kalkulus (Kambalyal, Kambalyal P, \& Hungund, 2015). Perokok cenderung memiliki kebersihan mulut yang lebih buruk dan nilai rata-rata plak yang lebih tinggi dibandingkan dengan non-perokok (Gupta et al., 2016). Obat-obatan antihipertensi dapat menyebabkan keluhan seperti xerostomia, pembesaran gingiva, pembengkakan dan nyeri pada kelenjar saliva, perubahan pada sensasi rasa, dan parastesia (Kumar, Mastan, Chowdhary, \& Shanmugam, 2012). Penderita diabetes melitus akan lebih mudah terkena infeksi karena perubahan pada pembuluh darah dan saraf, tidak terkecuali infeksi pada rongga mulut. Karies, dental abses, lesi ulseratif oral dan candidiasis merupakan manifestasi rongga mulut yang sering terjadi pada individu dengan diabetes. Penderita diabetes juga akan merasakan mulut kering karena penurunan aliran saliva (Veiga et al., 2018).

Pengetahuan masyarakat terutama wanita mengenai berbagai kondisi yang berhubungan dengan penyakit dalam rongga mulut harus menjadi perhatian karena perubahan hormonal pada saat kehamilan dan menopause hanya dialami oleh wanita dan anatomi serta fisiologi tubuh wanita juga berbeda dengan pria sehingga lebih berisiko terkena penyakit mulut. Salah satu upaya yang dapat dilakukan untuk meningkatkan pengetahuan tersebut adalah dengan melakukan penyuluhan sebagai bentuk dari promosi kesehatan. Perubahan perilaku ke arah pola hidup yang sehat merupakan hasil yang diharapkan melalui pemberian penyuluhan (Kemenkes, 2011; Nur'aeny et al., 2018).

Desa Cikeruh merupakan salah satu desa yang memilikipermasalahan dibidangkesehatan. Saranadan prasarana kesehatan yang belum memadai, partisipasi dan kesadaran masyarakat untuk berperilaku sehat masih rendah, dan belum maksimalnya penyuluhan atau sosialisasi dari pihak-pihak terkait merupakan serangkaian penyebab permasalahan bidang kesehatan di desa Cikeruh. Berdasarkan data-data tersebut maka peneliti bermaksud melakukan penyuluhan mengenai kondisi tubuh yang berhubungan dengan penyakit dalam rongga mulut pada wanita di Desa Cikeruh.

\section{METODE}

Populasi dari kegiatan adalah kelompok wanita dalam keadaan hamil, menopause, mempunyai penyakit sistemik diabetes melitus, hipertensi serta wanita perokok di Desa Cikeruh. Sampel yang memenuhi kriteria inklusi diambil secara keseluruhan (total sampling). Didapatkan 81 wanita peserta penyuluhan dari Desa Cikeruh.

Penyuluhan dilaksanakan menggunakan media tatap muka secara daring menampilkan paparan dengan power point dan pemutaran video melalui aplikasi zoom meeting karena kondisi pandemi Covid-19 yang tidak memungkinkan penyuluhan dilaksanakan secara tatap muka langsung. Materi penyuluhan berisi pemaparan mengenai kondisi sistemik maupun perubahan hormonal secara fisiologis seperti kehamilan dan menopause, serta keadaan patologis seperti diabetes mellitus dan hipertensi, juga kebiasaan buruk seperti merokok yang bermanisfestasi pada keadaan klinis di tubuh maupun rongga mulut.

Kegiatan penyuluhan terdiri dari tiga tahap yaitu pemberian pre-test, penyampaian materi penyuluhan oleh narasumber dan post-test. Pre dan post-test memiliki pertanyaan yang sama dengan jawaban tertutup ya/tidak, terbagi atas lima topik yaitu diabetes melitus, hipertensi, kehamilan, menopause dan kebiasaan merokok. Pre dan posttest dibagikan kepada peserta melalui google form. Daftar pertanyaan pre dan post-test berisi tanda/ gejala baik yang bermanifestasi di tubuh maupun rongga mulut yang berkaitan dengan kondisi diabetes mellitus, hipertensi, kehamilan, menopause, serta kebiasaan merokok.

\section{HASIL DAN PEMBAHASAN}

Penyuluhan yang dilakukan di Desa Cikeruh diawali dengan pengumpulan data penyakit tidak menular yang didapat dari Puskesmas Jatinangor dalam kurun waktu Juli 2018-Juni 2019. Hasil pada data tersebut menunjukkan bahwa penderita penyakit hipertensi dengan jenis kelamin pria di Kecamatan Jatinangor sebanyak 134 orang, sedangkan dengan jenis kelamin wanita sebanyak 148 orang. Penderita penyakit diabetes melitus dengan jenis kelamin pria sebanyak 40 orang dan dengan jenis kelamin wanita sebanyak 53 orang. Hal ini menunjukkan bahwa pada penyakit tidak menular yakni hipertensi dan diabetes mellitus, wanita memiliki resiko yang lebih tinggi dibandingkan pria. Data dari Klinik Padjadjaran dalam kurun waktu Juli 2018-Juni 2019 didapatkan 46 wanita di Desa Cikeruh menderita penyakit hipertensi dan 10 wanita di Desa Cikeruh menderita penyakit diabetes mellitus. Hal ini menunjukkan bahwa $31 \%$ wanita yang menderita penyakit hipertensi di Kecamatan Jatinangor, terdapat di Desa Cikeruh, dan 19\% wanita yang menderita penyakit diabetes mellitus di Kecamatan Jatinangor terdapat di Desa Cikeruh.

Penyuluhan kesehatan adalah salah satu bentuk pendidikan kesehatan yang bertujuan untuk merubah sikap dan perilaku masyarakat sesuai dengan tujuan penyuluhan. Unsur-unsur penyuluhan sebagai media pendidikan non-formal meliputi persepsi, kognisi dan afektif (Machfoedz \& Suryani, 2009). Peningkatan 
pengetahuan mengenai kesehatan memengaruhi akan kebiasaan pemeliharaan kesehatan individu (Adilah, Wardani, \& Zubaedah, 2018).

Kegiatan penyuluhan dilaksanakan pada hari Sabtu tanggal 18 Juli 2020. Nilai rata-rata pre dan post-test semua topik ditunjukkan oleh Gambar 1. Peningkatan nilai rata-rata peserta kegiatan penyuluhan pada post-test terlihat pada kelima topik. Hasil ini sesuai dengan beberapa penelitian yang menyatakan bahwa terdapat peningkatan pengetahuan pada responden yang telah diberi perlakuan berupa penyuluhan (Muthia, Fitriangga, \& Yanti, 2016; Wardani, Widyastika, Ardiana, Sila, \& Asri, 2018; Widyasari \& Candrasari, 2010). Responden dapat menambah pemahaman melalui materi yang diberikan selama penyuluhan sehingga mendorong terjadinya perubahan perilaku (Muthia et al., 2016).।

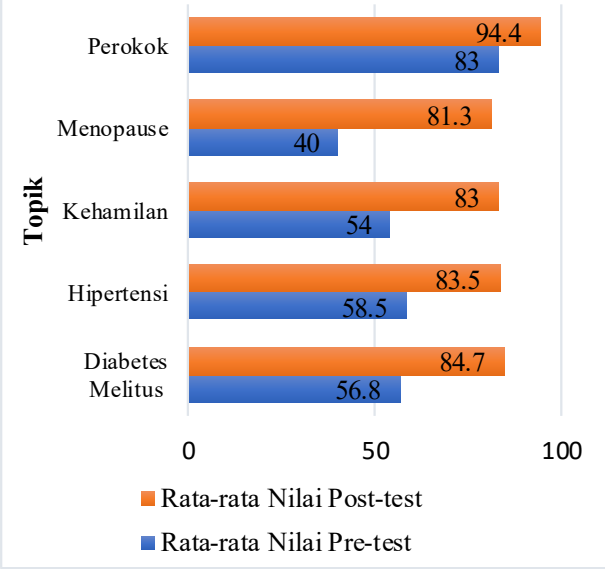

Sumber: Hasil Perhitungan Sendiri

Gambar 1. Nilai rata-rata pre dan post-test Responden Berdasarkan Topik Penyuluhan

Sebanyak 76 orang (93.8\%) responden mengalami peningkatan nilai rata-rata pada post-test. Lima orang $(6,1 \%)$ responden yang memiliki penurunan nilai rata-rata post-test merupakan ibu hamil. Hal ini mungkin disebabkan karena ibu hamil cenderung lebih mudah lelah karena durasi penyuluhan yang cukup panjang yaitu satu jam. Ibu hamil juga dapat mengalami penurunan durasi tidur sehingga menyebabkan penurunan konsentrasi (Bambang, 2006).

Tabel 1. Hasil Pretest dan Postest Kelompok Diabetes Mellitus

\begin{tabular}{llcc}
\hline \multirow{2}{*}{ No } & \multirow{2}{*}{ Kategori } & \multicolumn{2}{c}{ Jumlah Responden } \\
\cline { 3 - 4 } & & Pre-test & Post-test \\
\hline 1 & Sangat Baik & 14 & 60 \\
2 & Baik & 20 & 12 \\
3 & Sedang & 11 & 3 \\
4 & Kurang & 36 & 6 \\
\hline
\end{tabular}

Sumber: Hasil Perhitungan Sendiri
Tabel 1 menunjukan hasil peningkatan pengetahuan mengenai penyakit diabetes mellitus serta dampak terhadap tubuh dan rongga mulut dari responden. Sejumlah 60 responden masuk ke dalam kategori sangat baik setelah penyuluhan.

Tabel 2. Hasil Pre-test dan Post-test Kelompok Hipertensi

\begin{tabular}{|c|c|c|c|}
\hline \multirow{2}{*}{ No } & \multirow{2}{*}{ Kategori } & \multicolumn{2}{|c|}{ Jumlah Responden } \\
\hline & & Pre-test & Post-test \\
\hline 1 & Sangat Baik & 17 & 62 \\
\hline 2 & Baik & 15 & 8 \\
\hline 3 & Sedang & 8 & 6 \\
\hline 4 & Kurang & 41 & 5 \\
\hline
\end{tabular}

Sumber: Hasil Perhitungan Sendiri

Tabel 2 menunjukan hasil peningkatan pengetahuan mengenai penyakit hipertensi serta dampak terhadap tubuh dan rongga mulut. Sejumlah 62 responden masuk ke dalam kategori sangat baik setelah dilakukan penyuluhan.

Tabel 3. Hasil Pre-test dan Post-test Kelompok Hamil

\begin{tabular}{llcc}
\hline \multirow{2}{*}{ No } & \multirow{2}{*}{ Kategori } & \multicolumn{2}{c}{ Jumlah Responden } \\
\cline { 3 - 4 } & & Pre-test & Post-test \\
\hline 1 & Sangat Baik & 14 & 56 \\
2 & Baik & 6 & 6 \\
3 & Sedang & 9 & 9 \\
4 & Kurang & 52 & 10 \\
\hline
\end{tabular}

Sumber: Hasil Perhitungan Sendiri

Tabel 3 menunjukan hasil peningkatan pengetahuan mengenai kehamilan serta dampaknya pada tubuh dan rongga mulut. Sejumlah 56 orang responden masuk ke dalam kategori sangat baik setelah penyuluhan.

Tabel 4. Hasil Pre-test dan Post-test Kelompok Menopause

\begin{tabular}{llcc}
\hline \multirow{2}{*}{ No } & & \multirow{2}{*}{ Kategori } & \multicolumn{2}{c}{ Jumlah Responden } \\
\cline { 3 - 4 } & & Pre-test & Post-test \\
\hline 1 & Sangat Baik & 8 & 54 \\
2 & Baik & 4 & 9 \\
3 & Sedang & 62 & 3 \\
4 & Kurang & & 15 \\
\hline & & Sumber: Hasil Perhitungan Sendiri
\end{tabular}

Tabel 4 menunjukan hasil peningkatan pengetahuan mengenai menopause. Sejumlah 54 responden masuk ke dalam kategori sangat baik setelah dilakukan penyuluhan. 
Pengetahuan dan keterampilan yang baik dapat diperoleh salah satunya dengan cara penyuluhan Penyuluhan merupakan upaya untuk meningkatkan pengetahuan dan kemampuan seseorang melalui teknik praktik belajar atau instruksi dengan tujuan mengubah perilaku, baik secara individu maupun kelompok sehingga kesadaran untuk memelihara kesehatan dapat meningkat (Susilowati, 2016).

Rongga mulut merupakan gerbang menuju bagian dalam tubuh. Oleh karena itu, kesehatan rongga mulut dapat berpengaruh kepada kesehatan tubuh secara keseluruhan dan pola hidup sehat, jika tidak dijaga dengan baik dapat menimbulkan penyakit. Menurut World Dental Federation (FDI), penyakit gigi dan rongga mulut dapat memengaruhi berbagai aspek kehidupan, mulai dari kepercayaan diri di sekolah, pekerjaan, maupun kemampuan berinteraksi dengan orang lain. Kondisi kesehatan yang tidak baik termasuk keadaan rongga mulut dapat mengakibatkan isolasi sosial dan mengurangi pendapatan sehingga menurunkan kualitas hidup.

Berdasarkan The Global Burden of Disease Study tahun 2016, hampir setengah populasi penduduk dunia (3,58 miliar jiwa) mengalami permasalahan kesehatan gigi dan mulut khususnya karies gigi. Hasil Riset Kesehatan Dasar (Riskesdas) tahun 2018 menyatakan bahwa proporsi terbesar masalah gigi di Indonesia ialah penyakit gigi berlubang/rusak/sakit sebanyak 45,3\%. Sedangkan masalah kesehatan mulut yang mayoritas dialami penduduk Indonesia adalah gusi bengkak dan atau abses sebesar $14 \%$. Tingginya angka kejadian pada penyakit gigi dan mulut tidak terlepas dari berbagai faktor resiko pemicunya (Riskesdas, 2018).

Perilaku merokok merupakan kebiasaan yang berdampak pada kesehatan dengan prevalensi paling tinggi. Merokok tidak hanya menimbulkan efek pada tubuh, tetapi juga dapat menyebabkan timbulnya kondisi patologis di rongga mulut. Gigi dan jaringan lunak rongga mulut, dapat mengalami mengalami kerusakan akibat rokok. Rongga mulut adalah bagian pertama yang terpapar efek rokok, karena merupakan tempat terjadinya penyerapan zat hasil pembakaran rokok. Komponen toksik dalam rokok serta gas asap dapat mengiritasi jaringan lunak rongga mulut, sehingga menyebabkan terjadinya infeksi mukosa, memperlambat penyembuhan luka, menurunkan kekebalan tubuh dengan melemahkan kemampuan fagositosis sel, menekan proliferasi osteoblas, serta dapat mengurangi asupan aliran darah ke gingiva. Efek lokal merokok terhadap gigi dan rongga mulut antara lain menyebabkan terjadinya radang gusi, penyakit periodontal, karies akar, alveolar bone loss, tooth loss, serta berhubungan dengan munculnya lesi-lesi khas pada jaringan lunak rongga mulut (Kusuma, 2011).
Menurut data Riskesdas tahun 2018, berdasarkan hasil pengukuran nasional, hipertensi merupakan salah satu penyakit dengan prevalensi tinggi dengan angka kejadian pada penduduk Indonesia usia lebih dari 18 tahun yaitu sebesar $34,11 \%$ dan berdasarkan hasil pengukuran menurut jenis kelamin, penderita hipertensi pada laki-laki sebesar 31,34 \% dan perempuan sebesar 36,85\% (Riskesdas, 2018). Walaupun angka kejadian yang tinggi, kebanyakan penderita tidak menyadari bahwa mereka menderita hipertensi karena seringkali tidak menimbulkan gejala, sementara tekanan darah terusmenerus dalam keadaan tinggi dalam jangka waktu lama dapat menimbulkan komplikasi yang akan membahayakan hidup penderita. Oleh karena itu, hipertensi kerap kali disebut The Silent Killer.

Munculnya berbagai kondisi patologis sistemik maupun lokal dalam rongga mulut, disebabkan karena terjadinya penurunan fungsi molekuler saliva. Kerusakan komponen antioksidan saliva, diikuti dengan penurunan fungsinya, ditemukan pada beberapa kelainan di rongga mulut. Salah satu faktor yang menjadi perhatian adalah kalsium saliva. Kalsium merupakan salah satu komponen anorganik saliva yang kadarnya dapat berubah berhubungan dengan penyakit mellitus tipe 2, demikian juga kehamilan memiliki hubungan dengan penurunan kadarkalsium sehingga memicu demineralisasi email. Begitu juga dengan kebiasaan merokok, menopause dan hipertensi juga akan meningkatkan kadar kalsium sehingga dapat memicu penumpukkan plak dan kalkulus. Penurunan maupun peningkatan kadar kalsium saliva ini akan menimbulkan atau bahkan memicu perubahan lingkungan di dalam rongga mulut serta akan meningkatkan resiko penyakit mulut. Penyakit rongga mulut yang akan timbul yaitu karies dan penyakit periodontal (Tjahajawati, Rafisa, Gumilar, Nurzanah, \& Rikmasari, 2021). Berbagai penelitian menunjukkan bahwa tingkat karies yang lebih tinggi pada wanita dapat dijelaskan karena perbedaan dalam komposisi saliva dan laju aliran, fluktuasi hormon selama pubertas, menstruasi dan kehamilan, serta variasi genetik. Laju aliran saliva dan analisis komposisi saliva telah terbukti secara umum kurang bersifat protektif pada wanita dibandingkan pada laki-laki, sehingga menjadi sumber kerentanan pembentukan karies pada perempuan. Prevalensi karies yang lebih tinggi di antara perempuan secara gender dikaitkan dengan adanya erupsi gigi yang lebih cepat sehingga paparan gigi mereka lebih lama ke lingkungan oral kariogenik, akses yang lebih mudah terhadap makanan, kebiasaan mengemil dan perubahan nutrisi selama kehamilan, dan faktor sosial (Ferraro \& Vieira, 2010; Rahardjo, Widjiastuti, \& Prasetyo, 2016).

Menurut Kementrian Kesehatan (Kemenkes) 
tahun 2016, dewasa ini dari setiap 100 perempuan Indonesia 7 diantaranya adalah perokok aktif. Angka ini dipastikan terus meningkat seiring dengan perkembangan industri. Hasil Riskesdas membuktikan terjadi peningkatan prevalensi perokok perempuan di Indonesia dari $2.5 \%$ pada 2016 menjadi $4.8 \%$ pada 2018. Padahal perempuan memiki resiko mengalami penyakit gigi yang lebih tinggi daripada laki-laki terutama pada penyakit karies dan periodontal (Kemenkes, 2020).

Besarnya dampak merokok, penyakit komorbid diabetes mellitus dan hipertensi serta perubahan hormon pada wanita terhadap kesehatan gigi dan rongga mulut dapat mengganggu produktivitas dan menurunkan kualitas hidup. Peningkatan jumlah perempuan perokok di Indonesia menjadi dasar perlu dilakukan survei pada masyarakat mengenai seberapa tingkat pemahaman dan pengetahuan yang diperoleh mengenai kesehatan tubuh dan rongga mulut. Perlu diadakan kegiatan yang memberikan edukasi mengenai bahaya merokok dan berbagai penyakit serta perubahan hormon yang dapat timbul khususnya pada wanita dengan harapan responden dengan kondisi yang beresiko ini mendapat motivasi lebih memperhatikan kesehatan tubuh dan rongga mulut.

Pengabdian kepada masyarakat merupakan salah satu dari tridharma Perguruan Tinggi.

Tenaga pendidik mempunyai pola pikir yang diharapkan dapat memberikan solusi terhadap permasalahan yang terjadi di masyarakat. Bidang ilmu kesehatan, hendaknya dapat mengambil peranan penting dalam mengedukasi dan memotivasi masyarakat untuk menjaga kesehatan tubuh dan rongga mulut, dengan memberikan gambaran tentang berbagai bahaya merokok, diabetes mellitus, hipertensi dan perubahan hormone perempuan yang berhubungan dengan dengan kelainan pada gigi dan ronggamulut. Terlebih lagikondisipandemi Covid-19 berdampak pada kondisi ekonomi dan mengganggu mobilitas sehingga masyarakat kesulitan dalam mendapatkan akses ke fasilitas kesehatan salah satunya untuk mendapatkan pelayanan terhadap gigi dan rongga mulut sehingga diharapkan masyarakat dapat lebih mandiri dalam melakukan pencegahan terhadap masalah gigi dengan mengelola kesehatan tubuh dan rongga mulut dengan lebih baik.

Keterbatasan penelitian ini adalah waktu penyuluhan yang hanya dilakukan dalam tiga kali pertemuan zoom dengan durasi masingmasing pertemuan selama dua jam. Pada tahap selanjutnya dapat dilakukan penyuluhan upaya mencegah penyakit gigi dan mulut dengan cara memberikan penyuluhan cara menyikat gigi yang benar, penggunaan pasta gigi yang mengandung fluor, mengurangi makanan manis dan lengket, membiasakan mengkonsumsi makanan berserat dan menyehatkan gigi, serta memeriksakan gigi secara berkala sedikitnya dalam jangka waktu 6 bulan sekali.

\section{SIMPULAN}

Kegiatan penyuluhan pada wanita di Desa Cikeruh menunjukkan peningkatan pengetahuan mengenai dampak dari kondisi tubuh seperti diabetes melitus, hipertensi, kehamilan, menopause dan kebiasaan merokok terhadap tubuh serta hubungannya dengan penyakit dalam rongga mulut. Kegiatan penyuluhan ini diharapkan dapat mendorong para peserta kegiatan dan masyarakat untuk merubah perilaku ke arah pola hidup yang lebih sehat.

\section{UCAPAN TERIMAKASIH}

Kami mengucapkan terima kasih kepada para kader PKK yang telah membantu terselenggaranya penyuluhan di Desa Cikeruh.

\section{DAFTAR PUSTAKA}

Adilah, B. H., Wardani, R., \& Zubaedah, C. 2018. Perbedaan status kebersihan gigi dan mulut pada siswa Pondok Pesantren Salafiyah AlMajidiyah sebelum dan sesudah penyuluhan. J Ked Gi Unpad. 30 (2) 76-84.

Bambang, B. R. 2006. Upaya preventif di bidang kesehatan ibu dan anak sebagai upaya untuk meningkatkan daya saing bangsa. Jurnal Kesmas. 1 (2) 69-74.

Fábián, T. K., Fejérdy, P., \& Csermely, P. 2008. Saliva in health and disease, chemical biology of. Wiley Encyclopedia of Chemical Biology. 1-9. doi:10.1002/9780470048672.wecb643

Ferraro, M., \& Vieira, A. R. 2010. Explaining Gender Differences in Caries: A Multifactorial Approach to a Multifactorial Disease. International Journal of Dentistry. 2010 649643. doi:10.1155/2010/649643

Gupta, V. V., Chitkara, N., Gupta, H. V., Singh, A., Gambhir, R. S., \& Kaur, H. 2016. Comparison of Salivary Calcium Level and $\mathrm{pH}$ in patients with Aggressive Periodontitis and Healthy Individuals: A Clinico -Biochemical Study. OHDM. 15 (2) 122-126.

Kambalyal, P., Kambalyal P, \& Hungund, S. 2015. Comparison of salivary calcium level in smokers and non-smokers with chronic periodontitis, aggressive periodontitis, and healthy controls. J Int Soc Prev Community Dent. 5 (2) 68-73.

Upaya Peningkatan Pengetahuan Wanita Mengenai Kondisi Tubuh yang Berhubungan dengan Penyakit Rongga Mulut Melalui Penyuluhan (Sri Tjahajawati, Anggun Rafisa, Rasmi Rikmasari, dan Cucu Zubaedah) 
Kemenkes, R. I. 2011. Promosi Kesehatan di daerah bermasalah kesehatan, panduan bagi petugas kesehatan di Puskesmas.

Kemenkes, R. I. (2020). Situasi Kesehatan Gigi dan Mulut 2019. (https://www.kemkes.go.id/ article/view/20030900005/situasikesehatangigi-dan-mulut-2019.html, diakses 31 Juli 2020).

Kumar, P., Mastan, K., Chowdhary, R., \& Shanmugam, K. 2012. Oral manifestation in hypertensive patients: A clinical study. Journal of Oral and Maxillofacial Pathology. 16 (2) 215-221.

Kusuma, A. R. P. 2011. Pengaruh Merokok Terhadap Kesehatan Gigi Dan Rongga Mulut. Majalah Ilmiah Sultan Agung. 49 (124) 12-19.

Machfoedz, I., \& Suryani, E. 2009. Pendidikan kesehatan bagian dari promosi kesehatan. Yogyakarta: Fitramaya.

Muthia, F., Fitriangga, A., \& Yanti, R. S.A. S. N. 2016. Perbedaan efektifitas penyuluhan kesehatan menggunakan metode ceramah dan media audiovisual (film) terhadap pengetahuan santri Madrasah Aliyah Pesantren Khulafaur Rasyidin tentang TB paru tahun 2015. Jurnal Cerebellum. 2 (4) 646-656.

Nur'aeny, N., Wahyuni, I. S., Witadiana, H. S., Panoramawati, I. W., Hakim, D. D. L., Susilaningsih, F. S., . . G Gurnida, D. A. 2018. Evaluasi Penyuluhan Nutrisi Seimbang dan Pengenalan Sariawan pada Siswa di SDN 1 Tempuran Karawang. Dharmakarya. 2 (3) 268-272.

Rahardjo, A. K., Widjiastuti, I., \& Prasetyo, E. A. 2016. Prevalensi Karies Gigi Posterior Berdasarkan Kedalaman, Usia Dan Jenis
Kelamin Di Rsgm Fkg Unair Tahun 2014. Conservative Dentistry Journal. 6 (2) 66-70.

Riskesdas. 2018. Laporan Nasional 2018. Jakarta: Badan Penelitian dan Pengembangan Kesehatan Kementerian RI

Rockenbach, M. I., Marinho, S. A., Veeck, E. B., Lindemann, L., \& Shinkai, R. S. 2006. Salivary flow rate, $\mathrm{pH}$, and concentrations of calcium, phosphate, and sIgA in Brazilian pregnant and non-pregnant women. Head \& face medicine. 2 44-44. doi:10.1186/1746$160 \mathrm{X}-2-44$

Susilowati, D. 2016. Promosi Kesehatan. Jakarta: Pusdik SDM Kesehatan.

Tjahajawati, S., Rafisa, A., Gumilar, K. N., Nurzanah, F., \& Rikmasari, R. 2021. The impact of pregnancy and menopause on the correlation between salivary calcium levels, calcium intake, and bleeding on probing (BOP). J Int Soc Prevent Communit Dent. 11 (3) 324-331.

Veiga, N., Marques, T., Monteiro, A. S., Couto, J., Conceição, P., Matos, S., . . Coelho, I. 2018. Oral manifestations and diabetes. Biomed J Sci \& Tech Res. 7 (5) 6168-6171.

Wardani, R., Widyastika, K., Ardiana, O., Sila, I., \& Asri, R. T. 2018. Pengaruh pendidikan kesehatan Hipertensi terhadap pengetahuan Lansia di Posyandu Lansia Kelurahan Manisrenggo. Journal of Community Engagement in Health. 1 (2) 25-28.

Widyasari, \& Candrasari. 2010. Peningkatan pengetahuan tentang hipertensi pada Lansia di Posyandu Lansia Dukuh Gantungan desa Makamhaji Kartasura Sukoharjo. WARTA. 13 (1) 28-36. 